ks. Józef Cempura ${ }^{1}$

Uniwersytet Papieski Jana Pawła II w Krakowie

\title{
Czytania biblijne jako źródło przepowiadania podczas uroczystości \\ Najświętszego Serca Pana Jezusa
}

Doświadczenie miłości jest wpisane w życie każdego człowieka, dlatego tematyka związana z miłością była ważna w każdej epoce i nie traci na aktualności także we współczesnych czasach. Papież Benedykt XVI poświęcił temu zagadnieniu całą swoją encyklikę Deus caritas est. Podkreśla w niej harmonię występującą między dawaniem miłości drugim a jej otrzymywaniem od innych: „[...] kto chce dawać miłość, sam musi ją otrzymać w darze. Oczywiście człowiek może - jak mówi nam Chrystus - stać się źródłem, z którego wypływają rzeki żywej wody" (por. $\mathrm{J} 7,37-38)^{2}$.

Benedykt XVI wyjaśnia, że człowiek „takim źródłem” może stać się wtedy, gdy będzie pił ze zdroju, którym jest Zbawiciel. Od momentu kiedy

1 Ks. mgr lic. Józef Cempura - prezbiter ze Zgromadzenia Księży Najświętszego Serca Jezusowego. Święcenia kapłańskie przyjął w 2000 roku. Ukończył studium retoryki na wydziale Polonistyki Uniwersytetu Jagiellońskiego w Krakowie (2004). Pracował jako wikariusz w parafii w Binczarowej (2000-2003) oraz w Krakowie (2003-2007). Od roku 2007 posługujący w duszpasterstwie na Słowacji. Doktorant homiletyki na Uniwersytecie Papieskim Jana Pawła II w Krakowie. E-mail: jozefcempura@gmail.com.

${ }^{2}$ Por. Benedykt XVI, enc. Deus caritas est, 7. 
otwarto Jego bok, inspiruje wciąż na nowo do przemiany ludzkie serca w źródła żywej wody. Jednym ze środków pomagających w czerpaniu $\mathrm{z}$ bogactw Bożego Serca są czytania biblijne ${ }^{3}$ przeznaczone na święto Najświętszego Serca Pana Jezusa ${ }^{4}$.

Czytania te mogą posłużyć do odkrycia aktualności nabożeństwa do Bożego Serca i jego wpływu na życie wierzących. Stanowią one jedno ze źródeł przepowiadania w ciągu roku liturgicznego, chociaż w samą uroczystość wierni nie są zobowiązani do udziału w zgromadzeniu eucharystycznym ${ }^{5}$.

Ksiądz Krzysztof Napora, przeprowadzając refleksję nad zagadnieniem Serce Boga w Piśmie Świętym, zwraca uwagę na głęboką identyfikację „słowa Bożego i Bożego Serca”. Przytacza też zachętę Grzegorza Wielkiego, który bardzo trafnie precyzuje potrzebę czytania i rozważania słów Boga zapisanych w Piśmie Świętym: „[...] Przyłóż się do studium i rozważaj każdego dnia słowa twego Stworzyciela. Odkrywaj serce Boga w słowach Boga"'.

Niniejsze opracowanie podejmie zagadnienie treści tekstów biblijnych przewidzianych na uroczystość Najświętszego Serca Pana Jezusa oraz zasadniczych tematów teologicznych, które należy podjąć w głoszeniu homilii we wspomnianą uroczystość. W związku z tym najpierw dokonamy ogólnej prezentacji źródeł przepowiadania na uroczystość Bożego

3 Por. B. Nadolski, Czytania biblijne w liturgii, w: Leksykon liturgii, red. B. Nadolski, Poznań 2006, s. 291-292.

4 Lekcjonarz mszalny, t. 3, Okres zwykły od 1 tygodnia zwykłego do 11 tygodnia zwykłego, Poznań 2015, s. 483-494; zob. Lekcjonarz mszalny, t. 7, Czytania w Mszach obrzędowych, okolicznościowych, wotywnych, Poznań-Warszawa 1977, s. 482-511; na aktualność zagadnienia wskazują różne artykuły nawiązujące do uroczystości poświęconej Sercu Zbawiciela; zob. Dziś uroczystość Najśw. Serca Pana Jezusa, https://www.deon.pl/religia/kosciol-i-swiat/z-zycia-kosciola/art,19096,dzis-uroczystosc-najsw-serca-pana-jezusa (07.02.2018); Liturgiczne święto Boskiego Serca Pana Jezusa początkowo było przywilejem tylko dla Polski, http://gosc.pl/ doc/3204480.Uroczystosc-Najswietszego-Serca-Pana-Jezusa (07.02.2018).

${ }_{5}$ „[...] źródłem przepowiadania - obok Pisma Świętego - może być inny tekst święty, np. oracja, prefacja, śpiewy międzylekcyjne itp.”. Cyt. za: L. Szewczyk, Liturgia jako źródło homilii w przepowiadaniu kapłanów archidiecezji katowickiej w latach 1972-1999, „Ruch Biblijny i Liturgiczny" 57 (2004) nr 4, s. 281.

6 Por. K. Napora, Serce Boga w Piśmie Świętym, w: Serce Jezusa w misterium Kościoła. 250 lat kultu Serca Pana Jezusa w Polsce, red. W. Pałęcki, Z. Głowacki, Lublin 2016, s. 21-22. 
Serca zawartych w tekstach świętych, czyli biblijnych i liturgicznych. Następnie dokładniej omówimy teksty biblijne przewidziane na tę uroczystość, a na koniec zaprezentujemy główne tematy, które tego dnia powinni podjąć homiliści.

\section{Ogólna prezentacja źródeł przepowiadania na uroczystość Najświętszego Serca Pana Jezusa}

Konstytucja o liturgii świętej - owoc soboru watykańskiego II (KL 24, 35 , 52) wskazuje Pismo Święte oraz liturgię jako podstawowe źródła przepowiadania. Proklamując zbawcze dzieła Boże, które mają swe źródła w tekstach biblijnych, nie można pomijać kontekstu liturgicznego danego dnia .

Do roku 1970 był przewidziany tylko jeden formularz mszy świętej na święto Serca Pana Jezusa i na pierwsze piątki miesiąca. Według nowego Mszału rzymskiego ${ }^{8}$ Pawła VI zostały zredagowane dwa formularze: na uroczystość oraz na wotywę.

Mając na uwadze cel homilii, jakim jest wprowadzenie wiernych do udziału w zbawczej mocy proklamowanych wydarzeń, warto krótko zatrzymać się nad przewodnimi treściami tekstów liturgicznych przeznaczonych na uroczystość Najświętszego Serca Pana Jezusa. Do nich należą, oprócz trzech czytań, których treść będzie przedmiotem analizy w dalszej części artykułu: modlitwy prezydencjalne (kolekta, modlitwa nad darami oraz modlitwa po Komunii Świętej), antyfony, psalmy oraz prefacja9.

7 Por. L. Szewczyk, Liturgia jako źródło homilii..., dz. cyt., s. 279-280.

${ }^{8}$ „Mszał stanowi księgę zawierającą teksty stałe i zmienne Mszy Świętej oraz przepisy dotyczące jej sprawowania. Pierwsze posoborowe wydanie typiczne ukazało się w 1970 roku". Cyt. za T. Sinka, Liturgika. Zarys liturgiki, Kraków 1994, s. 42.

9 Por. H. Sławiński, Znaczenie lekcjonarza mszalnego $w$ kaznodziejstwie, „Studia Włocławskie" 6 (2003), s. 399-400. 
Mszał rzymski Pawła VI w rytuale mszalnym Cogitationes ${ }^{10}$ na uroczystość zachował drugą kolektę oraz modlitwę nad darami z rytuału Cogitationes 1929. Treść tekstu pierwszej kolekty nawiązuje do tej zawartej w Miserebitur ${ }^{11} \mathrm{z}$ wprowadzeniem zasadniczych zmian w jej drugiej części ${ }^{12}$. Pierwsza kolekta charakteryzuje się bezpośrednim zwrotem do Boga oraz oddaniem Mu czci w Jezusie Chrystusie, którego obrazem jest Serce Bożego Syna. W modlitwie przejawia się radość z objawienia miłości obecnej w Bożym Sercu.

Drugą kolektę również cechuje odwołanie się do Boga. On w Sercu Zbawiciela otrzymuje zadośćuczynienie. Modlitwa nad darami Cogitationes z 1929 roku w rytuale Cogitationes z 1970 roku została zachowana bez zmian. Jej początek odznacza się charakterem błagalnym względem Boga, po czym następuje koncentracja na miłości Jezusa Chrystusa. W treści modlitwy pojawia się też forma błagalno-ofiarna oraz wynagradzająca $^{13}$. Modlitwa po Komunii obejmuje prośbę, aby poprzez miłość Bożą, której doświadczają wierzący, oddając cześć Sercu Jezusa, osiągnęli umiejętność dostrzeżenia Zbawiciela w bliźnich ${ }^{14}$.

Kolejnym źródłem przepowiadania są antyfony ${ }^{15}$. W zestawie tekstów świątecznych na uroczystość Serca Pana Jezusa oraz w wotywie

10 Nazwa rytuału pochodzi od pierwszego słowa, które rozpoczyna formularz mszalny ustanowiony w liturgii na cześć Serca Jezusowego: „Cogitationes Cordis eius in generationem et generationem [...]”. Por. J. Hojnowski, Słownik kultu Serca Jezusowego, Kraków 2000, s. 49 .

11 „Miserebitur secundum multitudinem tuarum [...]”. Również w przypadku tegoż rytuału nazwa ma swoje źródło w słowie, które jest umiejscowione na jego początku. Formularz Miserebitur, zaaprobowany w roku 1765, był używany do roku 1929, kiedy został zamieniony przez rytuał Cogitationes. Por. J. Hojnowski, Słownik kultu..., dz. cyt., s. 155.

12 Por. W. Mocydlarz, Od „Miserebitur” do „Cogitationes”. Aspekty liturgiczne oraz teologiczno-pastoralne idee mszy o Najświętszym Sercu Jezusa, w: Serce Jezusa w misterium Kościoła. 250 lat kultu Serca Pana Jezusa w Polsce, red. W. Pałęcki, Z. Głowacki, Lublin 2016, s. 54-55.

13 Por. W. Mocydlarz, Serce Jezusa w liturgii, Kraków 2009, s. 90-109; por. także M. Augé, Rok liturgiczny. To sam Chrystus, który trwa w swoim Kościele, Kraków 2013, s. 244-245.

14 Por. I. Słoma, Serce Jezusa w formularzach mszału rzymskiego, „Liturgia Sacra” 21 (2015), nr 1, s. 112.

15 W liturgii antyfony ukonstytuowały się w kontekście przygotowywania śpiewu psalmów. Wpływały na ton oraz nastrój przebiegających celebracji. Miały charakter wezwań do radości w związku z przeżywaną uroczystością (np. introit). Były też ograniczane do recytowania albo używano ich w sekwencjach. Teksty antyfon zwykle miały źródło w Biblii 
formularz mszalny zawiera po jednej antyfonie na wejście oraz dwie na Komunię. W introicie występują dwa wersety Psalmu 32; część wiersza 11 i cały wiersz 19: „Zamysły Jego Serca trwają przez pokolenia, aby ocalić od śmierci życie tych, którzy Mu ufają, i żywić ich w czasie głodu". Wybrane wersety pochodzą z psalmu określanego jako Hymn na cześć Stwórcy. Podkreśla on, że Bóg się troszczy o swój lud i całe swoje stworzenie.

Rytuał mszalny obejmuje dwie antyfony na Komunię. Obydwie pochodzą z Ewangelii św. Jana: „Pan mówi: Jeśli ktoś jest spragniony, a wierzy we Mnie, niech przyjdzie i pije. Strumienie wody żywej popłyną z jego wnętrza” (J 7, 37-38) lub „Jeden z żołnierzy włócznią przebił bok Jezusa i natychmiast wypłynęła krew i woda" (J 19, 34).

Dalszym źródłem dla proklamacji Bożego słowa są psalmy. Księga Psalmów, z której zostały wybrane teksty na uroczystość Najświętszego Serca Pana Jezusa w roku A oraz w roku C, jest hebrajskim dziełem literackim wyrażającym duchowe życie narodu wybranego. Podobnie jak prowadziła w przeszłości, tak i dziś prowadzi naród izraelski. Towarzyszy też blisko 2000 lat uczniom Chrystusa.

Zatrzymując się nad treścią psalmów responsoryjnych przeznaczonych na uroczystość Najświętszego Serca Pana Jezusa, warto zwrócić uwagę na fakt, że niektórzy liturgiści zaliczają psalmy do tekstów kerygmatycznych, mimo iż w liturgii słowa wskazuje się na dwa lub trzy czytania. Według ks. Bogusława Nadolskiego psalmy są proklamacją słowa Bożego. Charakterystyczna jest dla nich forma wygłaszania słowa Bożego, czyli śpiew. Melodia ma stanowić pomoc w zgłębianiu treści psalmu, a powtarzany werset pomaga skupić uwagę na chrystologicznym sensie tekstu ${ }^{16}$. W takim znaczeniu ma rolę medytacyjną względem słowa Bożego.

W roku liturgicznym przewidziano teksty psalmów responsoryjnych na uroczystość Najświętszego Serca Pana Jezusa, podobnie jak

\footnotetext{
albo w literaturze wczesnochrześcijańskiej. Antyfony na Komunię powstawały od X wieku, natomiast antyfony po Komunii w XII wieku. Jeszcze wcześniej, bo od IV wieku był praktykowany śpiew podczas Komunii; por. także W. Mocydlarz, Serce Jezusa wliturgii, dz. cyt, s. 213.

16 Por. B. Nadolski, Psalm responsoryjny - słowo Boże śpiewane, w: Msza Święta-rozumieć, aby lepiej uczestniczyć. Wykład liturgii Mszy, red. J. Hadalski, Poznań 2013, s. 220.
} 
w przypadku czytań przyporządkowując je poszczególnym cyklom ${ }^{17}$. W roku A jest przewidziany fragment Psalmu 103 (102), 1b - $2.3-4.6$ 7.8 i 10. Refren akcentuje przewodnią myśl utworu: „Bóg jest łaskawy dla swoich czcicieli". Psalm ten jest hymnem uwielbienia oraz dziękczynienia ${ }^{18}$. Pierwsza część Psalmu 103 (w. 2-10) wychwala przymioty Boże, jakimi są miłość oraz przebaczenie. Druga część poświęcona wychwalaniu wiecznej miłości Boga wskazuje także na ludzką słabość. Autor natchniony zachęca medytujących i modlących się tymi słowami do zawierzenia się Bogu. Przekonuje, aby porzucili to, co jest nietrwałe i przemijające, oraz by przyjęli zaproszenie do udziału w wieczności Bożej ${ }^{19}$. Autor psalmu pośród radosnej pieśni o charakterze dziękczynnym oraz hymnu, którym wielbi Boga, czyni główną myślą prawdę o Jego miłosierdziu. Fundamentalną jedność treści psalmu można zawrzeć w słowach św. Jana mówiących, że „Bóg jest miłością” $(1 \mathrm{~J} 4,8)^{20}$. On jest Nauczycielem i wzorem miłości.

Na rok B jako psalm responsoryjny został wybrany urywek z 12 rozdziału Księgi Izajasza (Iz 12, 2.3 i 4bcd. 5-6) (R.: por. 3). Refren swoją treścią nawiązuje nie tylko do psalmu, ale także do Ewangelii: „Będziecie czerpać ze zdrojów zbawienia”. Psalm ten stanowi pieśń mesjańską. Należy on do tekstów, które mają charakter psalmiczny. Odwołuje się do wywyższenia Boga oraz faktu przeminięcia lęku. Po tych wydarzeniach Boży wybrańcy „będą czerpać ze źródeł zbawienia”21. Bóg Ojciec z otwartym sercem daje swojego Syna, aby człowiek mógł korzystać z daru Jego obecności.

Wspólnota liturgiczna z ufnością spogląda na swoją przyszłość, ponieważ Święty Izraela to ten, który gwarantuje wypełnienie zawartego przymierza z Izraelem. Temat zbawienia jest kontynuacją myśli zawartej w rozdziałach poprzedzających wspomnianą pieśń, która zachęca

17 Lekcjonarz mszalny, t. 3, dz. cyt., s. 484-492.

18 Por. G. Ravasi, Psalmy „modlitwą ludu Bożego”, tłum. F. Gołębiowski, Częstochowa 1998, s. 31.

19 Por. G. Ravasi, Księga czwarta (Ps 90-106) i piąta (Ps 107-150), w: Międzynarodowy komentarz do Pisma Świętego: Komentarz katolicki i ekumeniczny na XXI wiek, red. W. R. Farmer, wyd. pol. W. Chrostowski, Warszawa 2000, s. 735.

20 Por. G. Ravasi, Psalmy „modlitwą ludu Bożego”, dz. cyt., s. 31-33.

21 Por. A. M. Pelletier, Księga Izajasza, w: Międzynarodowy komentarz do Pisma Świętego..., dz. cyt., s. 862 . 
do radości z powodu przyjścia na świat zapowiadanego Emmanuela (Iz 7-11). On przyniesie światu sprawiedliwość i pokój. Chrześcijanie, którzy są „przy zdrojach zbawienia”, zostali zaproszeni do rozgłaszania wszystkim narodom wielkich dzieł, które Bóg zrealizował z miłości do człowieka ${ }^{22}$.

Psalm responsoryjny przeznaczony na rok C jest nazywany Psalmem ufności ${ }^{23}$. Główne przesłanie Psalmu 23 (22), 1b - 3a. 3b - 4.5.6 znajduje się w wersecie 4: „Chociażbym chodził ciemną doliną, zła się nie ulęknę, bo Ty jesteś ze mną. Twój kij i Twoja laska są tym, co mnie pociesza" (w. 4). Refren, podobnie jak w roku B, wyraźnie znajduje swoje odzwierciedlenie czy też kontynuację w Ewangelii, a brzmi: „Pan mym pasterzem, nie brak mi niczego".

Treść psalmu w pierwszej części tworzy obraz sceniczny, w którym dominuje atmosfera nieustannego ruchu i niebezpieczeństwa. W dalszej części wprowadza w atmosferę radości i odpoczynku. W biblijnym znaczeniu słowo „odpoczynek” wskazuje na zbawienie oraz bezpieczeństwo, które jest darowane w głównej mierze przez Mojżesza ${ }^{24}$. Określenie to przypomina również o miłości i wierności Boga względem narodu wy-

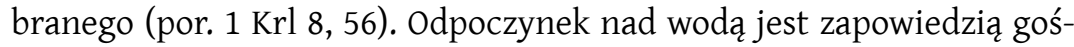
cinności Boga. Natomiast napełniony kielich świadczy o przyjaźni, jaką Bóg darzy człowieka. Zastawiony stół wskazuje na bezpieczeństwo. Dla Izraelity takim bezpieczeństwem cechował się dom, w którym przebywa Bóg. On może nasycić głód i pragnienie człowieka podczas modlitwy. Zaprasza do uczestniczenia w swoim życiu poprzez liturgię. On jest tym Ojcem, który kocha swoje dzieci oraz chce pośród nich przebywać. Dlatego przygotował dom, do którego zaprasza.

Do źródeł przepowiadania należy także modlitwa nazywana prefacją. Ona stanowi początek najważniejszej części składającej się na liturgię mszy świętej, zwanej modlitwą eucharystyczną. Uwielbienie i dziękczynienie należą do istoty tej modlitwy, którą zanosi kapłan. Przedmiotem

22 Por. Nowy Komentarz Biblijny, Stary Testament, t. 22, cz. 1, Księga Izajasza, rozdziały 1-12, wstęp, przekł. z oryginału, komentarz T. Brzegowy, Częstochowa 2010, s. 658.

23 Por. G. Ravasi, Modlitwa życiem w Psalmach, tłum. D. Piekarz, Kraków 2003, s. 84.

24 Por. G. Ravasi, Psalmy „modlitwą ludu Bożego”, dz. cyt., s. 107-108. 
dziękczynienia i uwielbienia przedstawianego Bogu Ojcu są Jego nieprzebrane dzieła zrealizowane w dziejach zbawienia.

Formularz Cogitationes z Mszału Pawła VI przewiduje jedną prefację zarówno na uroczystość, jak i na wotywę. Składa się ona z jednolitego tekstu euchologijnego, który upowszechnia i przypomina o wielkich dziełach Bożych oraz wychwala Boga za dar zbawienia, który się zrealizował na krzyżu, a najpełniej się wyraża w otwartym Sercu Zbawiciela ${ }^{25}$. Zastosowana syntaktyka pomaga w przyjęciu wiarygodności sceny ukrzyżowania i następstw, które potem z tym wydarzeniem były związane: „On wywyższony na krzyżu, w swojej nieskończonej miłości ofiarował za nas samego siebie. Z Jego przebitego boku wypłynęła krew i woda, i tam wzięły początek sakramenty Kościoła, aby wszyscy ludzie, pociągnięci do otwartego Serca Zbawiciela, z radością czerpali ze źródeł zbawienia"26.

W krótkiej prezentacji podstawowych źródeł przepowiadania na uroczystość Najświętszego Serca Pana Jezusa nie sposób wyczerpać myśli, które są w nich zawarte, oraz treści wymagających dalszej analizy. Główna myśl, wokół której można prowadzić przepowiadanie, kieruje do otwartego Serca Bożego, niewyczerpanego źródła zbawienia. Przewodnia treść modlitw prezydencjalnych, antyfon, psalmów oraz prefacji akcentuje zaproszenie Boga do odpowiedzi na ten dar zbawienia zaproponowany i objawiony przez Bożego Syna.

25 Por. W. Mocydlarz, Serce Jezusa w liturgii, dz. cyt., s. 122.

26 Zob. Mszał rzymski 2002 - Pref., 494; cyt. za W. Mocydlarz, Serce Jezusa w liturgii, dz. cyt., s. 122;

"Qui, mira caritate, exaltatus in cruce,

pro nobis tradidit semetipsum,

atque de transfixo latere sanguinem fudit et aquam,

ex quo manarent Ecclesiae sacramenta,

ut omnes, ad Cor apertum Salvatoris attracti,

iugiter haurirent e fontibus salutis in gaudio". 


\section{Analiza tekstów czytań}

Msza święta Cogitationes z roku 1970 na uroczystość Najświętszego Serca Pana Jezusa ma własny zestaw dziewięciu tekstów czytań na rok A, B i C ${ }^{27}$. Wotywa została wzbogacona o szerszy zestaw czytań dopełniających teksty wybrane na uroczystość ${ }^{28}$, przy czym formularz świąteczny może być użyty także przy wotywie.

Z formularzem jest związana księga zwana Lekcjonarzem, zawierająca perykopy czytań przeznaczonych na rok liturgiczny ${ }^{29}$. Czytania, które obejmuje lekcjonarz mszalny, są częścią liturgii. Uwydatniają istotę niedziel oraz świąt roku kościelnego. Przewodnia myśl oparta jest na paschalnym misterium Jezusa Chrystusa. Akcentuje jedność Starego i Nowego Testamentu oraz dziejów zbawienia, w których Zbawiciel zajmuje centralne miejsce.

W roku liturgicznym na uroczystość Najświętszego Serca Pana Jezusa zostały dobrane czytania biblijne według zasady harmonizacji tematycznej. W cyklu A tekst pierwszego czytania pochodzi z Księgi Powtórzonego Prawa. Jest to fragment drugiej mowy wygłoszonej przez Mojżesza w kontekście ogłoszenia Dekalogu. W wypowiedzi tej mówca dookreśla Prawo, którym mają się kierować Izraelici przebywający na terenie Ziemi Obiecanej. Pomyślność narodu wybranego będzie zależna od jego wierności wobec przekazanego Prawa. Cały fragment tekstu pierwszego czytania początkowo był interpretowany w kontekście dążeń Izraelitów do zjednoczenia w czasie wygnania oraz po powrocie. Dostrzegano w nim również istotę nauki według tradycji deuteronomicznej o Bożym wybraniu, powołaniu do świętości, przynależności do Boga, jego bezwarunkowej miłości względem praojców narodu wybranego, jak również ich potomków ${ }^{30}$. Już w pierwszym czytaniu można dostrzec, że „Bóg Ojciec ma pokorne Serce”. Dając Izraelitom Dekalog, ukazuje ludziom

27 Lekcjonarz mszalny, t. 3, dz. cyt., s. 483-494.

28 Por. W. Mocydlarz, Od „Miserebitur”..., dz. cyt., s. 53.

29 Por. T. Sinka, Liturgika..., dz. cyt., s. 42.

30 Por. W. Mocydlarz, Serce Jezusa w liturgii, dz. cyt., s. 139. 
swój obraz, który można określić w słowach: „Bóg z Sercem Nauczyciela”. Tę prawdę najpełniej objawi Jezus Chrystus Boży Syn.

Drugie czytanie to fragment Pierwszego Listu św. Jana. Apostoł podkreśla w nim, że Bóg jest najwyższym źródłem miłości, a w Jezusie Chrystusie może człowiek znaleźć wzór, jak tę miłość praktykowaćin Miłość prowadzi do zjednoczenia człowieka z Bogiem. Bez miłości Boga nie istnieje autentyczna miłość względem bliźniego ani wierność Bożym przykazaniom. Dzięki kontemplacji działania Boga przede wszystkim w Osobie Jezusa Chrystusa człowiek ma możliwość poznać istotę Boga, a dokładnie to, że jest miłością, miłość zaś jest charakterystycznym rysem dzieci Bożych. Podczas gdy w Starym Testamencie nikt nie miał możliwości widzieć Boga, w Nowym Testamencie Bóg objawia się w Jezusie Chrystusie i daje każdemu człowiekowi poznać siebie i czerpać ze źródła miłości, które jest niewyczerpalne. Syn Boży obdarza ludzi pełnią życia ${ }^{32}$.

Werset poprzedzający Ewangelię: „Weźcie moje jarzmo na siebie i uczcie się ode Mnie, bo jestem cichy i pokorny sercem" (Mt 11, 29ab) jest jej zapowiedzią. Tworzy cząstkę Ewangelii i wskazuje na jej główną myśl i przesłanie.

Trzecie czytanie w cyklu A stanowi perykopa z Ewangelii św. Mateusza. Ewangelista przedstawia w niej problem odrzucenia Jezusa Chrystusa przez tych, ku którym kieruje On zaproszenie do udziału w królestwie Bożym. Wybrany fragment pozwala dostrzec wezwanie Zbawiciela do odkrycia tajemnicy Jego intymnej relacji do Ojca ${ }^{33}$. Godny uwagi jest fakt, że w tekście św. Mateusza znajduje się tytuł „Pan nieba i ziemi”, którym Jezus Chrystus nazywa Boga Ojca. Tytuł ten występuje jedynie w Ewangelii Mateusza. Najczęściej Jezus Chrystus w odniesieniu do Boga Ojca używa określenia: „Ojcze mój” ${ }^{34}$. W Ewangelii według św. Mateusza

31 Por. Komentarz praktyczny do Nowego Testamentu, t. 2, red. L. Stachowiak, PoznańKraków 1999, s. 570; por. także J. Pietraszko, Otwarte Chrystusowe Serce. Medytacje pierwszopiątkowe, Kraków 2001, s. 88.

32 Por. Komentarz praktyczny do Nowego Testamentu, t. 2, dz. cyt., s. 570; por. także P. Warchoł, Krew $i$ woda dar Miłości miłosiernej, Warszawa 2015, s. 338-339.

33 Por. W. Mocydlarz, Serce Jezusa w liturgii, dz. cyt., s. 140.

34 Por. Komentarz praktyczny do Nowego Testamentu, t. 1, red. L. Stachowiak, PoznańKraków 1999, s. 72-73. 
można dostrzec „Jezusa z Sercem cichym i pokornym” (Mt 11, 25-30). Zatrzymując się nad treścią tej perykopy, zauważamy, że ewangelista przedstawia „Jezusa z Sercem Nauczyciela”. Już w pierwszych wersetach można dostrzec naukę wypływającą z uwielbienia Ojca wyrażonego w słowach Jezusowej modlitwy: „Wysławiam Cię, Ojcze, Panie nieba i ziemi, że zakryłeś te rzeczy przed mądrymi i roztropnymi, a objawiłeś je prostaczkom. Tak, Ojcze, gdyż takie było Twoje upodobanie”. Następnie Chrystus wskazuje na swoją relację do Ojca. Wydaje także świadectwo o swojej relacji do ludzi. Zaprasza tych, którzy doświadczają ciężarów życia, aby przyszli z nimi do Niego. On ich nie zdejmie, ale uczyni lekkimi oraz słodkimi, przez co zostanie uwielbiony Ojciec.

Pierwsze czytanie na uroczystość Serca Pana Jezusa w cyklu B zostało wzięte z Księgi proroka Ozeasza (Oz 11, 1.3-4.8c-9). Myśl przewodnia prorockiej mowy Ozeasza bazuje na przykładzie jego własnego małżeństwa oraz dzieci, które się w nim zrodziły. Mimo oskarżenia i potępienia duchowych przywódców Narodu Wybranego przez Boga, tekst wskazuje na Jego wielką miłość względem Izraela. Tę miłość nie mogą ograniczyć grzechy, takie jak niewdzięczność czy wiarołomstwo, które przyczyniają się do upadku Narodu Wybranego. Właśnie na tę nieograniczoną, bezwarunkową oraz miłosierną miłość Boga względem człowieka wskazuje tekst Księgi Ozeasza przeznaczony na liturgię tego święta ${ }^{35}$.

Dwa fragmenty Listu św. Pawła do Efezjan (Ef 3, 8-12.14-19) stanowią drugie czytanie, w którym apostoł przedstawia Bogu Ojcu w modlitwie naocznych świadków swojego nauczania. Chce, aby byli wzmocnieni wewnętrznie, poznając źródło wszelkiego życia, którym jest między innymi miłość Jezusa Chrystusa.

Śpiew poprzedzający Ewangelię stanowią dwa wersety do wyboru: jeden z Ewangelii św. Mateusza (Mt 11, 29ab): „Weźcie moje jarzmo na siebie i uczcie się ode Mnie, bo jestem cichy i pokorny sercem [...]" oraz drugi z Pierwszego listu św. Jana (1 J 4, 10b): „Bóg sam nas umiłował i posłał Syna swojego jako ofiarę przebłagalną za nasze grzechy”.

35 Por. J. L. Sicre Diaz, Duchowość proroków, w: Historia duchowości. Duchowość Starego Testamentu, t. 1, red. A. Fanuli i in., tłum. A. Pierzchała, Kraków 2002, s. 319-320. 
Treścią Ewangelii przeznaczonej na rok B jest wydarzenie, które odbyło się w atmosferze przeżywania święta Paschy żydowskiej w Jerozolimie. Jezus Chrystus Boży Syn podwyższony na krzyżu dokonuje dzieła zbawienia świata. Tekst ten należy do Janowej Księgi znaków. Ewangelista jako naoczny świadek przekazuje fakt śmierci Jezusa. Wskazuje na przebicie Jego boku oraz na krew i wodę, które wypływając ze zranionego boku, stają się bogatymi symbolami określającymi opisaną rzeczywistość. Przekazane wydarzenie zawiera bogate znaczenie w kontekście biblijnym oraz historio-zbawczym fragmentu Ewangelii przeznaczonej na święto Serca Jezusa. Należy zaakcentować fakt, że cała przewodnia myśl przepowiadania podczas uroczystości ma swoje źródło w Ewangelii św. Jana, który przekazuje świadectwo o przebitym boku Jezusa (J 19, 3137). W tym fragmencie Ewangelii jest przedstawiony "Jezus z otwartym Sercem”. Ewangelista podkreśla czas, w którym dokonało się otwarcie boku Zbawiciela. Wydarzenie zrealizowało się w „uroczysty dzień szabatu". Wyjątkowość tego dnia łączy się z faktem, że dokładnie w tym roku i tego dnia przypadała Pascha. Szczególnym znakiem, który nie może ujść uwadze przepowiadającemu Boże słowo, są krew i woda wypływająca z przebitego ciała Zbawiciela. Szczegół ten prowadzi do wcześniejszej zapowiedzi Chrystusa, którą św. Jan zaznaczył w 7 rozdziale swojej Ewangelii (J 7, 37-38). W tekście występuje bardzo wyraźne odniesienie do świadectwa wyrażonego przez tego, „który to widział”. Jest on jednym z naocznych świadków wspomnianego wydarzenia obok Matki Jezusa Chrystusa, a także Marii, która była żoną Kleofasa, Marii Magdaleny oraz żołnierzy ${ }^{36}$. Ewangelista zwraca uwagę na wypełnienie zapowiedzi zawartej w Piśmie: „Nie będziecie łamać jego kości” (Wj 12, 46). Przewodnią myśl tego fragmentu Ewangelii można ująć w słowach: „Jezus z Sercem otwartym”. Kolejny temat, który mógłby być rozwinięty podczas przepowiadania na podstawie fragmentu z Ewangelii św. Jana, obejmuje zagadnienia z zakresu chrystologii, pneumatologii oraz eklezjologii ${ }^{37}$. Główną

36 Por. Komentarz praktyczny do Nowego Testamentu, t. 1, dz. cyt., s. 572-573.

37 Por. J. Ratzinger, Tajemnica Wielkiej Nocy jako najgłębsza treść i postawa kultu Serca Jezusowego, w: Tajemnica Jezusa Chrystusa, Kielce 1994, s. 48-49. 
problematykę można określić słowami: „Jezus z Sercem, które jest życiodajnym źródłem sakramentów".

Perykopa z Księgi Ezechiela stanowi treść pierwszego czytania na uroczystość w cyklu C. Tekst jest częścią wyroczni mówiącej o nadziei związanej z odnową narodu wybranego (Ez 34, 11-16). Przekazuje proroctwo dotyczące dobrego Pasterza oraz owiec. Dobrym Pasterzem będzie sam Bóg, który mówi o sobie: „Ja sam będę pasł moje owce i Ja sam będę je układał na legowisko [...] Zagubioną odszukam, zabłąkaną sprowadzę z powrotem, skaleczoną opatrzę, chorą umocnię [...]" (Ez 34, 15-16).

Drugie czytanie pochodzi z Listu św. Pawła do Rzymian (Rz 5, 5b-11). Wybrany fragment stanowi część doktryny, którą apostoł kieruje do pogan. W niej wyjaśnia Ewangelię Bożą o Zbawicielu i Panu. Jezus Chrystus dokonał usprawiedliwienia człowieka oraz darował mu zbawienie, kierując się miłościąą

W śpiewie przed Ewangelią są proponowane, podobnie jak w cyklu B, do wyboru dwa wersety. Pierwszy stanowi fragment z Ewangelii św. Jana: "Ja jestem dobrym pasterzem i znam owce moje, a moje Mnie znają, [...]" $(\mathrm{J} 10,14)$. Natomiast drugi fragment pochodzi z Ewangelii św. Mateusza, w którym Pan Jezus wskazuje na swoje serce, zapraszając wiernych, aby Go naśladowali: „Weźcie moje jarzmo na siebie i uczcie się ode Mnie, bo jestem cichy i pokorny sercem [...]" (Mt 11, 29ab).

Do trzeciego czytania została wybrana perykopa $z$ Ewangelii według św. Łukasza, w której przedstawiona jest podróż Zbawiciela w kierunku Jerozolimy. Tam zrealizują się wszystkie Jego przepowiednie dotyczące męki, śmierci i zmartwychwstania. Podczas tej podróży Jezus przybliża w trzech obrazach miłosierdzie swojego Ojca. Fragment przeznaczony na uroczystość dotyczy zagubionej owcy utożsamionej z grzesznym człowiekiem, który zawsze może liczyć na pomoc przychodzącą ze strony zatroskanego Boga. Jest On w przypowieści przedstawiony w obrazie dobrego Pasterza, który po znalezieniu zagubionej owcy przygotowuje dla przyjaciół i znajomych ucztę. W dalszej części Pan Jezus wyjaśnia sens przypowieści: „[...] Powiadam wam: Tak samo w niebie większa będzie

38 Por. W. Mocydlarz, Serce Jezusa w liturgii, dz. cyt., s. 142; por. także Komentarz praktyczny do Nowego Testamentu, t. 2, dz. cyt., s. 30-32. 
radość z jednego grzesznika, który się nawraca, niż z dziewięćdziesięciu dziewięciu sprawiedliwych, którzy nie potrzebują nawrócenia" (Łk 15, 4-7). Następnie w dalszej części Ewangelista uwydatnia wielkość Bożego miłosierdzia. Przypomina, że mimo odrzucenia, jakiego doświadcza Syn Boży od mieszkańców Jerozolimy, którzy są obrazem grzesznego świata, Bóg w swoim miłosierdziu oczekuje na ich powrót z miłością ${ }^{39}$.

U św. Łukasza Ewangelisty jest zaakcentowany sposób bycia „Jezusa z Sercem Ojca, który kocha swoje dzieci” (Łk 15, 3-7). Już w pierwszym wersecie 15 rozdziału Ewangelista wskazuje na fenomen przybliżania się do Jezusa wszystkich ludzi oczekujących na dobre słowo, odpuszczenie i miłość: „Zbliżali się do Niego wszyscy celnicy i grzesznicy, aby Go słuchać”. W Jego postępowaniu ukazuje się całkowicie inne wartościowanie. Zdecydowanie różni się ono od osądu ludzkiego reprezentowanego przez uczonych w Piśmie i faryzeuszów: „Na to szemrali faryzeusze i uczeni w Piśmie: «Ten przyjmuje grzeszników i jada z nimi»"40.

Postawę Ojca przybliża Pan Jezus swoim słuchaczom na podstawie opowiadania, w którym charakteryzuje dwóch zagubionych synów. Stanowi ono kontynuację przypowieści o zagubionej owcy. Miłosierdzie ojca tam przedstawione charakteryzuje zachowanie Boga Ojca. Boży Syn jest obrazem Ojca i w relacjach do każdego grzesznego człowieka przyjmuje postawę, którą można określić: „Jezus z Sercem Ojca, który kocha swoje dzieci".

Wszystkie czytania biblijne przeznaczone na uroczystość pomagają zgłębić tajemnicę miłości Boga przedstawioną w symbolu Serca Jezusa. Rzeczywistość bogatej treści dotyczącej zbawczej miłości Boga objawionej w Osobie Wcielonego Słowa podkreśla papież Pius XII w encyklice Haurietis aquas: „Księgi Święte nie podają żadnej pewnej wzmianki o szczególnym kulcie czci i miłości względem fizycznego Serca Wcielonego Słowa jako symbolu żarliwej miłości. Ten oczywisty fakt nie powinien jednak budzić w nas zdziwienia ani przesłaniać nam innej prawdy, a mianowicie, że miłość Boża, będąca podstawową racją kultu Najświętszego Serca Jezusowego, została przedstawiona zarówno w Starym, jak i w Nowym

39 Por. W. Mocydlarz, Serce Jezusa w liturgii, dz. cyt., s. 142.

40 Lekcjonarz mszalny, t. 7, dz. cyt., s. 505. 
Testamencie w niezmiernie wzruszających obrazach. Obrazy te, przepowiadając niejednokrotnie przyjście Syna Bożego w ludzkiej postaci, mogą być uważane za zapowiedź znaku najwznioślejszej miłości Boga, jakim jest Najświętsze Serce Boskiego Odkupiciela" ${ }^{41}$.

W tym kontekście Księgi Starego i Nowego Testamentu wyraźnie wskazują na zbawczą miłość Boga objawioną w Osobie Wcielonego Słowa w symbolu Bożego Serca ${ }^{42}$. Jezus Chrystus jest obrazem niezgłębionej miłości Boga Ojca. Na tej podstawie teksty Pisma Świętego stanowią główne źródło, z którego należy czerpać inspirację do przepowiadania podczas uroczystości ku czci Bożego Serca ${ }^{43}$.

Pośród wypowiedzi autorów zajmujących się zagadnieniem nowych tekstów biblijnych przeznaczonych na celebrowanie liturgii ku czci Serca Jezusa można spotkać się z określeniem „niewyczerpany skarbiec pełen bogactwa i głębi przynoszący radość wierzącemu" ${ }^{44}$. Oprócz dziewięciu tekstów, które zostały wybrane na uroczystość Serca Jezusowego oraz przedstawione w niniejszym opracowaniu, wielkie bogactwo wnoszą 23 teksty przeznaczone na wotywę o Najświętszym Sercu, z których 14 jest nowych i nie były one proponowane na uroczystośćc ${ }^{45}$.

Wybrane teksty biblijne na święto czy wotywę o Sercu Pana Jezusa dają wiele możliwości zgłębiania bogactw, które zostały zdeponowane w Sercu otwartym dla wierzącego czy poszukującego człowieka, dla każdego. To Serce jest również dostępne dla wszystkich.

Warto zwrócić uwagę na jeszcze jeden moment ujęty przez Jana Ewangelistę. W swojej Ewangelii umieszcza istotne wydarzenie dotyczące otwartego boku po Chrystusowym zmartwychwstaniu. Przytacza

41 Pius XII, Haurietis Aquas, II, 1.

${ }^{42}$ Por. M. Auge, Rok liturgiczny..., dz. cyt., s. 244-246.

43 Por. W. Pietrzak, Formy przepowiadania o Sercu Jezusa. Uwagi homiletyczno-praktyczne, w: Misterium Serca Jezusa. Duchowość na III Tysiaclecie, red. J. Wełna, Warszawa 2007, s. 128.

44 Por. J. Gaweł, Liczy się miłość. W nurcie nauczania Jana Pawła II o Bożym Sercu w pierwsza rocznicę pielgrzymki do ojczyzny, Kraków 2000, s. 126-127.

${ }_{45}$ Więcej na temat treści tekstów na wotywę zob. Lekcjonarz mszalny, t. 7, dz. cyt., s. 482511. Oprócz tekstów już wymienionych na uroczystość do dodatkowych 14 z 23 należą następujące: Wj 34, 4b-6. 8-9; Pwt 10, 12-22; Iz 49, 13-15; Jr 31, 1-4; Ap 3,14b. 20-22; Ap 5, 6-12; Ef 1, 3-10; Flp 1, 8-11; Łk 15, 1-10; Łk 15, 1-3. 11-32; J 10, 11-18; J 15, 1-8; J 15, 9-17; J 17, 20-26. 
on scenę, w której Jezus Chrystus zaprasza Tomasza, aby zobaczył Jego rany na rękach, ale przede wszystkim ranę boku. „[...] Jezus przyszedł mimo drzwi zamkniętych, stanął pośrodku i rzekł: «Pokój wam!». Następnie rzekł do Tomasza: «Podnieś tutaj swój palec i zobacz moje ręce. Podnieś rękę i włóż [ją] do mego boku, i nie bądź niedowiarkiem, lecz wierzącym». Tomasz Mu odpowiedział: «Pan mój i Bóg mój!». Powiedział mu Jezus: «Uwierzyłeś, bo Mnie ujrzałeś; błogosławieni, którzy nie widzieli, a uwierzyli»" (J 19, 26-29).

Ten otwarty bok Zmartwychwstałego jest zaproszeniem do kontemplacji Jego obecności. Przypomnieniem rzeczywistości, że Serce Bożego Syna jest zatroskane, aby nie stracić nikogo. "Jezus jest z otwartym Sercem". Powierzeni Mu przez Ojca są bezpieczni (por. J 17, 11-12). On, znając dobrze serce człowieka i jego wątpliwości, zwraca się bezpośrednio do Tomasza z zaproszeniem, podobnie jak było w spotkaniu z Natanaelem. Tam Mistrz z Nazaretu w rozmowie przekonuje powołanego ucznia o doskonałym poznaniu go (por. J 1, 47-48). Tomasz Apostoł nie musi dotykać ran Mistrza. Wystarczy mu Jego obecność. Ona przekonuje go wraz z Jezusowym słowem, aby mógł wyznać swoją wiarę: „Uwierzyłeś, bo Mnie ujrzałeś; błogosławieni, którzy nie widzieli, a uwierzyli" (J 19, 29).

Otwarte rany na ciele Zmartwychwstałego są dla Chrystusowego ucznia bramą prowadzącą do wiary. Poprzez te chwalebne rany On, Boży Syn, pozwala, aby człowiek Go poznał. One stają się jednym wielkim znakiem rzeczywistości, że tylko Bóg obdarza życiem, które jest mocniejsze od śmierci.

Zmartwychwstały Chrystus z otwartym Sercem zaprasza każdego człowieka, aby tak jak Tomasz trwał w Jego obecności. Przy Jego zranionym Sercu wyznał wiarę i przyjął dar życia wiecznego.

\section{Zasadnicze tematy homilii}

Istotnie jedno ze źródeł inspirujących wierzącego do odpowiedzi na miłość Boga objawioną w Sercu Bożego Syna może stanowić refleksja i pochylenie się nad bogatym wyborem czytań biblijnych oraz tekstów 
liturgicznych. Ich treść daje wszystkim czcicielom Bożego Serca wielorakie propozycje i pomoc w przybliżeniu się do otwartego Serca Zbawiciela oraz naśladowaniu Jego miłości w codziennym życiu. Zachęcają one nie tylko do naśladowania, ale także przeżywania i praktykowania tej miłości względem Boga Ojca, bliźniego oraz siebie samego w zjednoczeniu z Nim. Mogą inspirować zarówno czciciela Serca Jezusa, jak i każdego człowieka o sercu otwartym na dary Zbawiciela. Jak przypominał papież Benedykt XVI: „[...] kto chce dawać miłość, sam musi ją otrzymać w darze" ${ }^{46}$.

W Dyrektorium o pobożności ludowej i liturgii znajduje się uzasadnienie istoty czci względem Najświętszego Serca Pana Jezusa. Tam dostrzegamy niezwykłość daru ofiarowanego człowiekowi z miłości: „W świetle Pisma Świętego wyrażenie «Serce Jezusa» oznacza misterium Chrystusa w ogóle, całe Jego istnienie, Jego Osobę rozumianą najgłębiej i istotowo: Syn Boży, Mądrość przedwieczna, nieskończona Miłość, źródło zbawienia i uświęcenie całej ludzkości. «Serce Jezusa» to Chrystus, Słowo wcielone i zbawiające, w Duchu Świętym istotowo zjednoczone z nieskończoną miłością bosko-ludzką do Ojca i do ludzi jako swoich braci" ${ }^{47}$. To w zgromadzeniu liturgicznym głoszone jest słowo Boże. Jak ważną rolę pełni w życiu wierzącego człowieka przepowiadanie, podkreśla ostatnio wydane Dyrektorium homiletyczne. Powyższą publikacją Kongregacja Kultu Bożego i Dyscypliny Sakramentów akcentuje znaczenie homilii. Pragnie, aby była ona: „rzeczywiście intensywnym i szczęśliwym doświadczeniem Ducha, pokrzepiającym spotkaniem ze Słowem, stałym źrodłem odnowy i wzrastania" (EG 135).

Dokument zwraca uwagę, że „[...] zadanie homilisty nie polega na tym, żeby dopasować czytania mszalne do jakiegoś uprzednio obmyślonego schematu zagadnień, lecz na zachęceniu słuchaczy do rozważania wiary Kościoła, która w naturalny sposób wyłania się z Pisma w kontekście celebracji liturgicznej" ${ }^{48}$. Godne uwagi są tematy proponowane przez

46 Por. Benedykt XVI, Deus caritas est, 7.

47 Dyrektorium o pobożności ludowej i liturgii, 166.

48 Dyrektorium homiletyczne, 159; por. także H. Sławiński, Chrystus urzeczywistnił Pismo. Homilie na rok A, Kraków 2007, s. 14-15. 
Dyrektorium homiletyczne na uroczystość Najświętszego Serca Pana Jezusa w cyklu A, B, C na podstawie Katechizmu Kościoła Katolickiego:

1. Miłosierdzie Boże (KKK 210-211, 604). Tekst uwzględnia czytanie proponowane na mszę świętą wotywną zaczerpnięte z Księgi Wyjścia (Wj 34, 4b-6.8-9) oraz z drugiego czytania na uroczystość Roku A z Pierwszego listu św. Jana Apostoła (1 J 4, 7-16), a także odwołuje się do drugiego czytania podczas uroczystości Roku C pochodzącego z Listu św. Pawła Apostoła do Rzymian (Rz 5, 5b-11).

2. Miłość Chrystusa do wszystkich (KKK 430, 478, 545, 589, 1365, 1439, $1825,1846)$. Tematyka oparta o teksty wybrane z trzeciego czytania w roku B, które stanowi fragment od św. Jana Ewangelisty (J 19, 31-37) oraz $\mathrm{z}$ trzeciego czytania w roku $\mathrm{C}$ na podstawie Ewangelii św. Łukasza (Łk 15, 3-7). Dalsze teksty pochodzą z czytań proponowanych na mszę świętą wotywną zaczerpniętych z Ewangelii św. Łukasza (Łk 15, 11-24) bazą jest tekst również z drugiego czytania wybranego z Listu św. Pawła Apostoła do Rzymian (Rz 5, 5b-11) na rok C. Kolejny tekst, z którego zaczerpnięto myśl do tematu, pochodzi z trzeciego czytania w roku C na bazie tekstu Ewangelii św. Łukasza (Łk 15).

3. Serce Chrystusa przedmiotem adoracji (KKK 2669). Problematyka oparta na fragmencie z Ewangelii św. Jana przeznaczonym na rok B jako trzecie czytanie.

4. Kościół zrodzony z przebitego boku Chrystusa (KKK 766, 1225). Również dla tego zagadnienia podstawę stanowi trzecie czytanie z Ewangelii św. Jana przewidziane na rok B (J 19, 31-37).

5. Miłość Chrystusa porusza nasze serca (KKK 1432, 2100). Główna myśl, mająca źródło w Ewangelii św. Jana (J 19, 31-37), pochodzi z trzeciego czytania przeznaczonego na rok B.

Medytowanie nad Bożym słowem przeznaczonym na święto Serca Pana Jezusa zawartym w Księgach Nowego i Starego Testamentu otwiera przed człowiekiem wierzącym szerszą perspektywę na spotkanie w Sercu Jezusa, na dotykanie tego Serca przez całą wieczność, tak jak Tomasz Apostoł, który odpowiedział na wezwanie Zmartwychwstałego: „Podnieś rękę i włóż [ją] do mego boku, i nie bądź niedowiarkiem, lecz wierzącym!”. 
Poprzez tajemnicę wcielenia Boży Syn umożliwił rzeczywistości duchowej, która w swojej naturze jest niewidzialna oraz niedotykalna objawienie się w cielesności, a także poprzez cielesność. Tę duchową rzeczywistość poprzez ludzkie ciało jest możliwe dostrzec wzrokiem oraz można jej dotknąć. Prawda ta została wyrażona w scenie przedstawiającej spotkanie Zmartwychwstałego Mistrza z niewiernym Tomaszem (por. J 20, 26-29).

Święty Jan Ewangelista przedstawia Tomasza wkładającego swoją rękę na wskazane przez Jezusa Chrystusa miejsce, jakim jest Jego przebity bok. Wątpiący Tomasz dotyka tego, co nie jest możliwe do dotknięcia. Widzi także to, co niewidzialne rzeczywistym sposobem. Do wspomnianej sceny nawiązuje w swoim dziele Tajemnica Wielkiej Nocy Joseph Ratzinger, akcentując tę rzeczywistość, która się realizuje w życiu Chrystusowego ucznia: „My wszyscy jesteśmy niewiernym Tomaszem; powinniśmy jednak, tak jak on, dotknąć otwartego Serca Jezusa, a przez to dotknać samego Logosu, spojrzeć Nań, i tak, zwracając rękę i oczy na to Serce, wyznać: «Pan mój i Bóg mój!»" 49.

Tomasz wyznał swoją wiarę. Jezusowe rany są wciąż otwarte, także po Jego zmartwychwstaniu stają się bramą do wiary. Do przyjęcia Chrystusa, Tego, który poprzez swoją mękę, śmierć oraz zmartwychwstanie jest źródłem dającym życie i zbawienie człowiekowi ${ }^{50}$.

$\mathrm{Na}$ zakończenie spróbujmy chociaż w części zasygnalizować możliwe do opracowania dalsze tematy przepowiadania z przeznaczeniem na uroczystość Serca Pana Jezusa:

A. Jezus z Sercem cichym i pokornym.

B. Jezus z Sercem Nauczyciela.

C. Jezus z otwartym Sercem.

D. Jezus z Sercem, które jest życiodajnym źródłem sakramentów lub Jezus $z$ Sercem dajacym życie.

E. Jezus z Sercem Ojca, który kocha swoje dzieci.

F. Jezus z Sercem dostęnnym dla wszystkich.

49 Por. J. Ratzinger, Tajemnica Wielkiej Nocy..., dz. cyt., s. 53.

50 Por. I. Słoma, Serce Jezusa w formularzach mszału rzymskiego, dz. cyt., s. 112. 
Współczesny chrześcijanin może znowu spotkać Zmartwychwstałego ze zranionym Sercem, który jak uczniom na drodze do Emaus wyjaśni Pisma i pomoże w poznawaniu i otwieraniu się na miłość Boga (por. Łk 24, 13-32). Jak Tomaszowi, który przeżywając dramat śmierci swojego Mistrza, trwając wobec Bożego Serca, wyznaje wiarę w obecność Zmartwychwstałego Pana i Boga (J 19, 27-28). Inspiracją niech będzie to symboliczne przypomnienie o bogatym źródle biblijnym zawartym w tekstach czytań przeznaczonych na święto Serca Pana Jezusa.

W tym kontekście bardzo trafne i inspirujące może być spostrzeżenie jednego z autorów podejmujących zagadnienie teologicznych fundamentów czci oddawanej miłości Boga objawionej w Bożym Sercu. W jednym ze swoich opracowań Chrystologia symboliczno-mistyczna u podstaw kultu Najświętszego Serca Jezusa zachęca on do kontemplacji miłości Boga do człowieka. Tam też podkreśla: „Między dwoma symbolami - boku i serca zachodzi ta różnica, że przebity bok odsyła do dramatu paschalnego, podczas gdy serce prowadzi do rozważania miłości jako ostatecznego sensu zamysłu Bożego zwieńczonego Paschą Chrystusa" ${ }^{51}$.

\section{Zakończenie}

Powyższe rozważania przypominają o konieczności głębszego spojrzenia na treści tekstów biblijnych i liturgicznych przy przepowiadaniu podczas uroczystości ku czci Serca Pana Jezusa. W wielu lokalnych wspólnotach wierzących oprócz tego święta dużą popularność miały praktyki dziewięciu pierwszych piątków miesiąca czy nabożeństw czerwcowych. Obecnie pośród wiernych jest dostrzegalny kryzys tegoż nabożeństwa ku czci Serca Zbawiciela, dlatego właściwy wydaje się powrót do źródeł, do Bożego Słowa, które stanowi jego fundament, oraz tekstów liturgicznych przeznaczonych na święto.

51 Por. J. Królikowski, Chrystologia symboliczno-mistyczna u podstaw kultu Najświętszego Serca Jezusa, w: Serce Jezusa w misterium Kościoła. 250 lat kultu Serca Pana Jezusa w Polsce, red. W. Pałęcki, Z. Głowacki, Lublin 2016, s. 32. 
Temat został ograniczony do problematyki: „Czytania biblijne jako jedno ze źródeł przepowiadania podczas uroczystości Najświętszego Serca Pana Jezusa”. Oprócz czytań biblijnych przewidzianych na wspomnianą uroczystość zostały zasygnalizowane treści tekstów liturgicznych, tj. modlitw prezydencjalnych, antyfon, psalmów, prefacji oraz tekstów czytań przeznaczonych na wotywę. Niezależnie od tego, czy są to teksty liturgiczne, takie jak np. kolekta, antyfona, psalm lub prefacja, mogą być dalszą podstawą do przygotowania tematu przepowiadania.

Po przedstawieniu tekstów biblijnych czytań zostały przypomniane znajdujące się w Dyrektorium homiletycznym propozycje tematów na podstawie Katechizmu Kościoła Katolickiego, do których należą: Miłosierdzie Boże (KKK 210-211, 604), Miłość Chrystusa do wszystkich (KKK 430, 478, 545, 589, 1365, 1439, 1825, 1846), Serce Chrystusa przedmiotem adoracji (KKK 2669), Kościół zrodzony z przebitego boku Chrystusa (KKK 766, 1225), Miłość Chrystusa porusza nasze serca (KKK 1432, 2100). Następnie zostały zaprezentowane główne tematy, które podczas uroczystości ku czci Serca Pana Jezusa powinni podjąć homiliści głoszący słowo Boże na podstawie czytań biblijnych: Jezus z Sercem cichym i pokornym, Jezus z Sercem Nauczyciela, Jezus z otwartym Sercem, Jezus z Sercem, które jest życiodajnym źródłem sakramentów, Jezus z Sercem Ojca, który kocha swoje dzieci, Jezus z Sercem dostęnym dla wszystkich.

Przepowiadanie podczas uroczystości ku czci Serca Pana Jezusa może podprowadzić uczestniczących w liturgii do zauważenia uprzywilejowanego momentu, jakim jest trwanie przy Sercu Zbawiciela, dotykanie tego, co niedotykalne, oraz dostrzeżenie tego, co niewidzialne.

Bóg, posyłając swojego jedynego Syna na świat, zaprosił wszystkich ludzi, aby uwierzyli w Jego miłość i przyjęli dar życia wiecznego. W podróży przez życie doczesne bezpiecznie może przeprowadzić Jezus Chrystus przepowiadany w Bożym słowie. To On jest tym „Jezusem z Sercem otwartym, z Sercem dającym życie, z Sercem cichym i pokornym, z Sercem Ojca, który kocha swoje dzieci, z Sercem dostępnym dla wszystkich". 


\section{Summary}

\section{Czytania biblijne jako źródło przepowiadania podczas uroczystości Najświętszego Serca Pana Jezusa}

Niniejsze opracowanie jest próbą ukazania bogatej treści tekstów biblijnych przewidzianych na uroczystość Najświętszego Serca Pana Jezusa oraz zasadniczych tematów teologicznych, które należy podjąć w głoszeniu homilii we wspomniane święto. Praca została ujęta w trzech częściach. W pierwszej części artykułu została dokonana ogólna prezentacja źródeł przepowiadania podczas mszy o Najświętszym Sercu na podstawie tekstów świętych. Następnie dokładniej przedstawiono i omówiono teksty biblijne przewidziane na tę uroczystość, a na koniec zaprezentowano główne tematy, które tego dnia powinni podjąć homiliści.

Słowa kluczowe: miłość Boga, Serce Jezusa, Msza o Najświętszym Sercu Pana Jezusa, źródło przepowiadania

\section{Bible Readings as a Source of Ppreaching During the Ceremony of Sacred Heart of Jesus}

The aim of the compilation below is to present the rich content of biblical readings used during the ceremony of the Sacred Heart of Jesus, as well as some basic theological themes which should be discussed during the homily of the aforementioned feast. The thesis consists of three parts. The first portion contains the general presentation of sources of preaching based on holy texts that represent the Sacred Heart of Jesus during the Mass. In the second portion, various liturgical texts assigned for this feast are discussed in further detail. Finally, the thesis specifies the main topics which should be preached on this holy day.

Keywords: love of God, Heart of Jesus, the Mass about the Sacred Heart of Jesus, source of preaching

\section{Bibliografia}

Augé M., Rok liturgiczny. To sam Chrystus, który trwa w swoim Kościele, tłum. K. Stopa, Kraków 2013.

Benedykt XVI, Encyklika Deus caritas est.

Nowy Komentarz Biblijny, Stary Testament, t. 22, cz. 1, Ksiega Izajasza, rozdziały 1-12, wstęp, przekł. z oryginału, komentarz T. Brzegow, Częstochowa 2010. 
Dziś uroczystość Najśw. Serca Pana Jezusa, https://www.deon.pl/religia/kosciol-i-swiat/z-zycia-kosciola/art,19096,dzis-uroczystosc-najsw-serca-pana-jezusa (27.06.2014).

Gaweł J., Liczy się miłość. W nurcie nauczania Jana Pawła II o Bożym Sercu w pierwsza rocznicę pielgrzymki do ojczyzny, Kraków 2000.

Hojnowski J., Słownik kultu Serca Jezusowego, Kraków 2000.

Katechizm Kościoła Katolickiego, Poznań 1994.

Komentarz praktyczny do Nowego Testamentu, red. L. Stachowiak, t. 1, PoznańKraków 1999.

Kongregacja ds. Kultu Bożego i Dyscypliny Sakramentów, Dyrektorium homiletyczne, Poznań 2015.

Kongregacja ds. Kultu Bożego i Dyscypliny Sakramentów, Dyrektorium o pobożności ludowej i liturgii. Zasady i wskazania, Poznań 2003.

Królikowski J., Chrystologia symboliczno-mistyczna u podstaw kultu Najświętszego Serca Jezusa, w: Serce Jezusa w misterium Kościoła. 250 lat kultu Serca Pana Jezusa w Polsce, red. W. Pałęcki, Z. Głowacki, Lublin 2016, s. 23-32.

Lekcjonarz mszalny, t. 3, Okres zwykly od 1 tygodnia zwyklego do 11 tygodnia zwyklego, Poznań 2015.

Lekcjonarz mszalny, t. 7, Czytania w Mszach obrzędowych, okolicznościowych, wotywnych, Poznań-Warszawa 1977.

Liturgiczne święto Boskiego Serca Pana Jezusa początkowo było przywilejem tylko dla Polski http://gosc.pl/doc/3204480.Uroczystosc-Najswietszego-Serca-Pana-Jezusa (23.06.2017).

Międzynarodowy komentarz do Pisma Świętego: Komentarz katolicki i ekumeniczny na XXI wiek, red. W. R. Farmer, red. wyd. pol. W. Chrostowski, Warszawa 2000, s. 731-748.

Mocydlarz W., Od "Miserebitur" do "Cogitationes". Aspekty liturgiczne oraz teologiczno-pastoralne idee mszy o Najświętszym Sercu Jezusa, w: Serce Jezusa w misterium Kościoła. 250 lat kultu Serca Pana Jezusa w Polsce, red. W. Pałęcki, Z. Głowacki, Lublin 2016, s. 33-61.

Mocydlarz W., Serce Jezusa w liturgii, Kraków 2009.

Mszał rzymski 2002.

Nadolski B., Czytania biblijne w liturgii, w: Leksykon liturgii, red. B. Nadolski, Poznań 2006, s. 291-294.

Nadolski B., Mszał, w: Leksykon liturgii, red. B. Nadolski, Poznań 2006, s. 990-992.

Nadolski B., Psalm responsoryjny - słowo Boże śpiewane, w: Msza Święta - rozumieć, aby lepiej uczestniczyć. Wykład liturgii Mszy, red. J. Hadalski, Poznań 2013, s. 220-222.

Napora K., Serce Boga w Piśmie Świętym, w: Serce Jezusa w misterium Kościoła. 250 lat kultu Serca Pana Jezusa w Polsce, red. W. Pałęcki, Z. Głowacki, Lublin 2016, s. 13-22.

Pelletier A. M., Księga Izajasza, w: Międzynarodowy komentarz do Pisma Świętego: komentarz katolicki i ekumeniczny na XXI wiek, red. W. R. Farmer, red. wyd. pol. W. Chrostowski, Warszawa 2000, s. 843-881.

Pietraszko J., Otwarte Chrystusowe Serce. Medytacje pierwszopiątkowe, Kraków 2001. 


\section{ks. Józef Cempura}

Pietrzak W., Formy przepowiadania o Sercu Jezusa. Uwagi homiletyczno-praktyczne, w: Misterium Serca Jezusa. Duchowość na III Tysiąclecie, red. J. Wełna, Warszawa 2007, s. $125-141$.

Pismo Święte Starego i Nowego Testamentu. Biblia Tysiąclecia, wyd. 4, PoznańWarszawa 1990.

Pius XII, Haurietis Aquas, II, 1.

Ratzinger J., Tajemnica Wielkiej Nocy jako najgłębsza treść i postawa kultu Serca Jezusowego, w: Tajemnica Jezusa Chrystusa, Kielce 1994, s. 48-49.

Ravasi G., Księga czwarta (Ps 90-106) i piąta (Ps 107-150), w: Międzynarodowy komentarz do Pisma Świętego: Komentarz katolicki i ekumeniczny na XXI wiek, red. W. R. Farmer, red. wyd. pol. W. Chrostowski, Warszawa 2000, s. 731-748.

Ravasi G., Psalmy „modlitwą ludu Bożego”, tłum. F. Gołębiowski, Częstochowa 1998, s. 31 .

Sicre Diaz J. L., Duchowość proroków, w: Duchowość Starego Testamentu, red. A. Fanuli, i in., tłum. A. Pierzchała, t. 1, Kraków 2002, s. 299-325 (Historia Duchowości, 1).

Sinka T., Liturgika. Zarys liturgiki, Kraków 1994.

Sławiński H., Chrystus urzeczywistnił Pismo. Homilie na rok A, Kraków 2007.

Sławiński H., Znaczenie lekcjonarza mszalnego w kaznodziejstwie, „Studia Włocławskie" 6 (2003), s. 386-403.

Słoma I., Serce Jezusa w formularzach mszału rzymskiego, „Liturgia Sacra” 21 (2015) nr 1, s. 107-114.

Szewczyk L., Liturgia jako źródło homilii w przepowiadaniu kapłanów archidiecezji katowickiej w latach 1972-1999, „Ruch Biblijny i Liturgiczny” 57 (2004) nr 4, s. 279-287. 